\title{
Workers Industrial Relations Response Course in Chinese Enterprises: Racialization Question at Industrial Parks in Tanzania
}

\author{
Migeto Zakaria Athumani ${ }^{1 *} \quad$ Weihe $\mathrm{GUO}^{2}$ \\ School of ethnology and sociology, Minzu University of china, 27 Zhongguancun South Avenue Beijing, China
}

Zip code : 100081

The research is financed by the program of initiative team of research of Minzu University of China (MUC)

Abstract

(Foreign Direct Investments) FDIs plays great role on promoting economic development of both the host country and place of their origin. Tanzania's recent move of industrialization witnesses a huge influx of Chinese foreign direct investments in special economic zones and industrial parks. With the increase of FDIs and industrial parks, cheap migrant laborers are of great importance to the development of these factories in industrial zones. Spending half a year in different Chinese enterprises and local owned companies in Tanzania, a field study was conducted on Chinese -Tanzanian labor racialization at Mkuranga industrial park in Tanzania. The analysis in this article is based on labor racialization at Mkuranga industrial zone where life course migration of workers, interactions in the workplace and Chinese workers interaction with surrounding environment. The study found that, while foreign enterprises improved livelihoods of migrant and local society at the park, there is racialization from both sides and is being fueled by total cultural misunderstanding.

Keywords: migrant workers, Chinese enterprises, racialization, Tanzania.

DOI: $10.7176 / \mathrm{DCS} / 10-11-08$

Publication date: November $30^{\text {th }} 2020$

\section{Introduction}

Africa was regarded as hopeless, corrupt and not just place to do business. Suddenly, Africa is the place to be and foreign investments is flooding in, and foreign powers are flooding in, some with even upscale influence than ever Joseph Patrick Ganahl (2013). Listening to the west and the Chinese you would think that they are in Africa to help Africans to help themselves. France wants to help Africa build democratic institutions, the Americans wants to help Africa to build security structures and the Chinese wants to help Africa build economic infrastructure. The question is, is Africans benefiting from the competition or is being squeezed and racialized by this new scramble1'2.

Unlike western powers, Chinese influence to Tanzania officially started soon after Tanganyika's independence. Tanganyika, the great bulk of today's Tanzania, established diplomatic relations with the People's Republic of China on December 9, 1961, the very same day that it gained independence Muhidin J. Shangwe (2017). Former Chinese Premier Zhou En Lai visited Tanganyika in January 1964 to set diplomatic relations in motion. Muhidin J. Shangwe added, when Tanganyika faced a mutiny by its army in January that year, China acted promptly to provide military assistance. China's assistance was the first to be publicly accepted by the Tanganyika government, marking the beginning of Beijing's support of the Tanzania People's Defense Force (TPDF) to this day

The rise of China is among the most discussed and watched topics in the fields of African Studies and International Relations. It is in 2000s when china engagements with Africa gained momentum. The time was marked by a very important milestone, the initiation of (Forum on China-Africa Cooperation) FOCAC which implies that china would expand its influence in Tanzania through investments

By common estimate, Africa has received a million or so of these Chinese newcomers in the space of a mere decade, during which time they have rapidly penetrated every conceivable walk of life: farmers, entrepreneurs building small and medium sized factories, and practitioners of the full range of trades, doctors, teachers, smugglers, prostitutes Howard W. French (2014).

International scholars' scrutiny is on what and how China is doing in Africa? Howard W. French (2014). This thesis aims to contribute the mostly discussed topic of Chinese enterprises operations presence in Africa/ Tanzania and what extents are Chinese embedded with industrial parks societies.

Chinese racialization on blacks is different from the west. While Chinese government regards Africans states as economic partners and the relation is a win-win3, it is absurd to deny Chinese racialization of Africans

1 The economist. https:/www.economist.com/leaders/2019/03/07/the-new-scramble-for-africa. Accessed Sept 7.2019

2 Aljazeera. Jul 27, 2014. https://www.youtube.com/watch?v=_KM06hTeRSY\&t=2188s. Accessed Sept 7.2019

3 China Daily 2018-10-03. http://www.chinadaily.com.cn/a/201810/03/WS5bb4da22a310eff303280a03.html. accessed Sept 8.2019 
labor and racist behaviors towards black Africans B Sautman (1994). The article is not trying indulging in governments' level relations rather down to people to people interfaces.

The study is centered on examining Chinese factory investment (Tang Co. pseudonym) in one of Tanzania newly established industrial park on the coast region of Pwani and SINOMA (Dar es salaam brunch) Tanzania group in three perspectives, 1) industrial parks factory workers; migrant peasant workers who move from unproductive peasant farming to newly industrial towns 2) Views and perspectives of Chinese/ Tanzanians workers at the factory at Mkuranga industrial park in Tanzania; personality and 3) Chinese racialization of labor in the factories and industrial park.

Based on direct participation in the field (Tang Co. pseudonym) in the industrial park, the paper argued on argument that, Chinese factories not only provides ample employments opportunities to young migrant laborers in Tanzania and Africa at large, but also unskilled labors suffers from Chinese low salary and racialization in the factory. This paper analytical grounds is built on the premises of racialization of local Tanzanian laborers in industrial parks; first, recruitment of factory laborers which is based on migration of rural peasant to industrial towns, the study analyses the origins and pattern of migrations in Tanzania, second, workshop interactions that is both Chinese and local laborers interaction in workplace which includes work ethics and stereotype perception among them and lastly life world interactions that's Chinese workers interaction with surrounding society and customs. Before looking at labor racialization, the paper takes a brief look at magnitude of Chinese industrial investments in Tanzania and its source of labor. Discovery of Chinese-Africans people to people relationships, racialization on pay and treatments is the main objectives. Industrial parks are new phenomenal in Tanzania and Chinese are majority investors in these parks therefore due to different culture, economy and political background, different racialization opinions at work place is bound to happen. This paper seeks to address just that.

\section{Foreign Enterprises and Tanzania industrial strategy}

Three presidents have already passed since Tanzania's move from socialist self-reliance economic approaches and shifted focus towards integration of Tanzania into the world economy through trade and investment. In 2000s there were not only very few Chinese enterprises in Tanzania but also fewer articles on Chinese investment appearing in the news economy. Intensive investment commitment stared in 2000 at China - Africa Cooperation (FOCAC) in Beijing where China declared was to expand investments and tourism cooperation with Tanzania which will benefit the two countries. In 2000s China's co-operation with Tanzania in particular has largely focused on agriculture Fujita M (2017). The cooperation where based on agricultural machinery which aimed at modernizing agriculture to increase production staple foods like rice and maize for export. Fujita Maho cited Xinhua net that, In 2006 China and Tanzania made a US\$ 17.5 million agreement to finance investments in agriculture 1.

The fifth president of Tanzania, Dr. John Joseph Magufuli aims at reaching the millennium goals of transforming Tanzania's economy to middle income economy by 2025 . To fulfill this aims, he has developed a strategy that encourages economic growth through industrialization which is in some ways similar to Nyerere's vision. History shows that, industrialization is the bold move to economic growth and poverty reduction. Ali A. Mufuruki and others noted that, Economic history shows us that essentially every single country in the world that has grown powerful over the recent decades and centuries has done so, not through free trade, but through strategic protectionism and an active industrial policy Ali A. Mufuruki et al (2017). To insure the move to industrialization in Tanzania, the government of Tanzania is supporting Tanzania's industrial plan through the establishment of an industrial development bank and reduction of taxes on locally produced goods. The Government also focuses on electricity development, which is a necessary step for achieving industrialization, President Magufuli announced. Industries, producing goods for mass consumption, such as clothes, textiles and edibles are encouraged. In order to accelerate industrialization, the President urged banks to lower interest rates for industrial projects during the President's Manufacturer of the Year Awards (PMAYA) on 31st May 20162.

According to Tanzania economic outlook report of 2016, Agriculture in Tanzania is an economic mainstay not only main contributor of GDP (five years ago in 2015 the agricultural sector contributed 29\% of the GDP compared to $28.8 \%$ in 2014)3, but also provide employment to most of common Tanzanians most of them are peasant farming. Discussed down, economic and environmental hardship peasants are facing in Tanzania to the extent of opting migration to towns as a livelihood strategy; migration to industrial Chinese investments enterprises is young peasant's livelihoods strategy where in turn are being racialized and treated differently. The main aim of president Magufuli is to diversify the peasant economy reliance to industrial economy, hence the

1 Xinhuanet, "China donates agricultural machinery to Tanzania, "Forum on China-Africa Cooperation, November 17, 2015, accessed March 14, 2017, http://www.fmprc.gov.cn/zflt/eng/jmhz/t222842.htm.

$2 \mathrm{https}: / /$ www.tanzaniainvest.com/industrialisation and follow us on www.twitter.com/tanzaniainvest Accessed August 8, 2019

$3 \mathrm{https}: / /$ www2.deloitte.com/content/dam/Deloitte/tz/Documents/tax/Economic\%20Outlook\%202016\%20TZ.pdf. Accessed August $9^{\text {th }}$, 2019, 3:43pm 
initiation of industrial parks as gateways in Tanzania. According to Burke and Corkin (2006), more than 85 Chinese-funded enterprises are active in Tanzania, and the number of Chinese entrepreneurs active in services such as construction, health and restaurants are ever-growing worth of US $\$ 2,142 \mathrm{~m}$ of foreign direct investments1. However most of these parks are located at the coast, meanwhile major agriculture and mining are at other inland Tanzania's region., there is there is an economic processing zone which is 12 kilometers from Dar es Salaam port and $14 \mathrm{~km}$ from Julius Nyerere International Airport, the 65-acre Benjamin Mkapa special economic zone, 300-acre Kamal Industrial Estate in Bagamoyo District and the newly developed Mkuranga Kisenvule industrial park to mention a few 2.

\subsection{Chinese Enterprises in Tanzania}

Some scholars argue that, of all foreign investors operating in Tanzania, Chinese investors comprise the largest group to have extensively invested in the tourism, textile, agriculture, electronics, mining, and infrastructure and manufacturing sectors among others3. Chinese manifestation on the African continent takes interwoven forms ranging from migration, development aid (including tariff exemptions and debt relief), trade, and investments (both state and privately driven) Dijk, M. P. v. (Ed.). (2009). China is increasingly becoming a major player in sub-Sahara Africa to the extent that in 2008 it replaced the European Union (EU) and the United States (US) as Africa's major trading partner with the main actors being the Chinese governments itself which plays the role of Trying to implement the government's strategy with respect to Africa and it coordinates the activities of different actors, state owned enterprises which goes to Africa as part of the official go out policy to assure the supply of raw materials, private Chinese companies which goes to Africa because they see opportunities there and fear cutthroat competition in the Chinese market, The Chinese Embassy in the country concerned plays the role of informing Chinese firms in the country concerned and coordinates activities of different actors and lastly Chinese people who are with different interests, but are driven by strong economic motives to go and work in AfricaJacoby (2007)

These actors are in Africa with different objectives. Dijk, M. P. v. (Ed.). (2009) mentioned these objectives as to Assure the supply of raw materials for China, including agricultural products, create a market for Chinese products and services, obtain land for agricultural purposes, channel migration of Chinese people to Africa,, gain diplomatic support from African countries, present an alternative to the Western development model, provide an alternative to Western development cooperation and lastly is to emphasize China's status as a superpower.

It is estimated that, China's trade with Africa zoomed to an estimated \$200 billion in 2012, a more than twentyfold increase since the turn of the century, placing it well ahead of the United States or any European country Howard W. French (2014). There is a rapid increase of foreign direct investment in Africa, with the biggest receiver of foreign direct investments in 2006 being Egypt (ten billion US\$), Nigeria (5.4 billion US\$), and Sudan (3.5 billion US\$). No doubt, most investments to Africa originate in Europe, the United States, and South Africa, but recently Asian countries have emerged as powerful investors in Africa (and elsewhere Dijk, M. P. v. (Ed.). (2009).

Although most of Asian foreign direct investments still targets nearby countries, recently they are turning their capital to African countries Meine Pieter van Dijk (2009). Throughout the 1990s, transnational corporations from Asian countries invested heavily in a few textile and garment producing countries in South and East Africa in order to overcome trade restrictions. Since then, especially Chinese companies have taken advantage of the fact that a number of resource-rich African countries have been avoided by Western investors due to political instability and bad governance. This has made large-scale investment in resource extractive activities possible $\mathrm{R}$ Kaplinsky (2009)

Chinese foreign direct investments to Africa resemble foreign direct investments from other sources in its concentration in a few (resource-rich) African economies. Likewise, the motives for investments mirror these of other companies in Africa, namely to get access to markets and resources Deborah Brautigam et al (2017).

Tanzania is among resources rich country ranging from mineral, oil, gas, tourism industrial raw materials to food products. Due to these foreign direct investments attractions, Tanzania receives massive direct investments from different part of the world. There are an increase number of Chinese enterprises in Tanzania in the recent years. The Citizen newspaper on Wednesday April 172019 reported Chinese ambassador to Tanzania Wang Ke speaking at Tanzania-china high-level investment and business environment dialogue which was attended by 100 Chinese companies operation in the country said,

"China has been Tanzania's largest trade partner for three consecutive years. China's total investments in Tanzania has exceeded to \$7billion which makes the Asian economic giant the largest foreign investors in the country".

1 https://nexia.com/insights/global-insight/investing-in-tanzania/. Accessed August 9, 2019

2 https://www.trademarkea.com/news/tanzania-economic-zones-key-to-industrialisation-says-meru/. Accessed August 9,2019

3 HPB Moshi \&JM Mtui (2008). Scoping studies of china- africa economic relation:the case study of Tanzania. Economic research bureau 11 
As discussed above, there is increasingly large quantity of Chinese investments in Tanzania, from construction, mining to factories. This article intends to study factory workers in Chinese enterprises and Chinese-local workers interaction in working and living places. However during analyzing, comparisons will be made with other none-Chinese factories presence in Mkuranga industrial park. But first let's look on labor mobilizations (Chinese) factories at Mkuranga industrial park.

\section{Labor Mobilization Techniques in Factories}

Labor supply in industrial zones usually depends on utilization on rural migrant labor. In China, at Shenzhen industrial zone Pun Ngai (2005:39) wrote, it is clear that the expansion of Shenzhen and its special economic zone is based on the mobility of migrants as temporary residents. These temporary migrant labors undertake most of manual labor in the special economic zone. Therefore, labor appropriation on economic development zones is unique in its use of temporary labor from rural areas. The mobilization of migrant labor or casual labor, which in china is termed as temporary labor (临时工/linshi gong), is one of distinctive elements of capitalism development in both developed countries in last century and in newly developing century Burrawoy (1976).

Tanzania's industrial zones like china's Shenzhen industrial zones at its early stage depended on mobilization of rural labor as part of the process for industrial takeoff and development. Unlike china, Tanzania labor movement and settlements is not controlled (through hukou like in china). There are different push and pull factors (will be elaborated soon) which facilitates the movement of peasant migrant labor to industrial town. Industrial zones are new phenomenal in Tanzania and most studies bases on international migration little domestic migration, even those shows domestic migration are outdated and don't explain current Tanzania industrial economy and its source of cheap labor K. Beegle (2011), Beegle et al (2011). Therefore there are fewer current studies showing migrant labor (migrant workers) in industrial areas rather labor migration in towns and big cities in Africa.

Due to the fact that special economic zones and industrial parks are new in Tanzania, there is lack of literatures on how migrant laborers in Tanzania's industrial parks are being mobilized, treated and recruited. Like Shenzhen special economic zone in China during China's industrial takeoff, Labor mobilization in Tanzania's industrial zones is based on peasant young migrant farmers migrating to these industrial towns seeking jobs as unskilled factory workers. there is less literatures regarding migrant labor in industrial park in Tanzania, but literatures show that Migration within the regions of Tanzania from both rural to urban and town to the city is dominated by young adults aging between 25-34 and adults aging 35-64, which are $29 \%$ and $61.2 \%$ respectively Robert Ebihart Msigwa (2013). However Ebihart Msigwa added, "In Tanzania, this move is significant because only subsistence agriculture, fishing and small scale mining invest in rural areas while the remaining economic activities such as industries are located in urban areas and cities, which are believed to be the magnets to attract migrants to cities and urban seeking for better life or to join the class".

Based on field worked conducted in Mkuranga industrial zone the research discovered that, 87 percent of workers at (Tang Company) were migrants from Tanzania inlands... Inlanders' boys and girls choose migration as their livelihood strategies to go to different towns seek for work. The recently Tanzania's move of initiation of industrial towns to attract foreign and domestic investments witnesses massive migration of young people seeking for jobs in factories.

There are several determinant acts as pushing and pulling factors of peasant migrant workers to industrial town in Tanzania. First of all, Tanzania labor migration went as far back as during colonial administration where colonialists established large estates of tea and coffee in the southern highlands and northern highlands of Kilimanjaro and sisal at the coast regions including Morogoro, Tanga, and Pwani and Dar es salaam, W. Rodney argued, the politics of production (labor process and labor apparatus) based of establishment of different tax policies like hut tax and head tax so as to create a condition for islanders(Buha, Sukuma, Nyamwezi and Ha ethnic group) need to look for money for tax payments. On describing the Buha's role as labor reserve, he argued, "the Ha were pushed into becoming migrant labor by colonial taxation and the monetization of social relations (especially bride wealthy), by administrative pressure and by absence of alternative ways of earning money, which was partly a result of the lack of official encouragement for cash crops" W. Rodney, K. Tambila and L. Sago (1983)

After colonial era, newly independent Tanzania's migration was more that of running from unproductive peasant economy for better city or town job. At the time government agricultural policy was less friendly to peasants in favor of industrial economy. On industrial and agricultural policy Robert Bates noted that, it can simply be understood that African countries agricultural policies are the culprit for the migration because of the condition it creates in rural areas and peasants. He wrote "there are government interventions in three major markets, first is market for agricultural goods which African government creates a single monopsony to buy peasants agricultural inputs in lower price. Second is market for inputs of farming which implies that governments provide little incents to peasants in Africa. The last is market for goods that farmers buy from urban-industrial sector in sense; these goods are of higher prices that peasants can't afford regarding that they 
income from agricultural goods reduced". Bates concluded that governments in Africa intend to transform their economies, they want to move resources from agriculture to industry and therefore they set agricultural goods prices in order to capture resources from agriculture Robert Bates (2014). Apart from climatic factor, these (agriculture and industrial) policies act as the pushing and pulling factor for migration to towns.

Many literatures also have linked migration to towns with climatic change that influence peasant farming in Africa/ Tanzania Clionadh Raleigh et al (2014), Caroline Zickgraf (2019). Study shows that Africa contributes to about 7 percent of global greenhouse gas emissions Chistiane Flohlich and silja Klepp (2018). Yet it remains highly vulnerable to the projected impact of climate change. According to World Bank Climate change is one of the biggest long-term challenges to global development. Africa is the hardest hit region in term of catastrophic natural disasters, the high vulnerability of the continent to the negative impact of climate change results from the fact that Africa as a whole has a high dependence on peasant farming, natural resources, poor infrastructure, pervasive poverty and weak institutional capacity to respond and mitigate environmental disasters effectively. In addition, the continent has a limited adaptive capacity, exacerbated by widespread poverty and the existing low levels of development Awil Mohamoud, Alpha Kaloga \& Sönke Kreft. (2014). The repercussions of climate change in Africa are, as observed so far, largely manifesting in changes in rainfall, accelerated deforestation and desertification World Bank (2013). Awil Mohamoud, Alpha Kaloga \& Sönke Kreft cited IPCC (2007) that by 2050, average temperatures in Africa are predicted to increase within a range of $1.5^{\circ} \mathrm{C}$ to $3^{\circ} \mathrm{C}$, while continuing to further increase beyond this time. Annual and seasonal warming throughout the African continent is very likely to be above the predicted global mean, with drier subtropical regions warming more than the moister tropics IPCC (2007). Therefore low rainfall leads to small yields hence famine therefore peasant farmers choose migration as their livelihood strategy.

\section{Racialization of Labor in Chinese Factory}

Racialization of Labor means the process of ascribing ethnic or racial identities to a relationship, social practice, or group that did not identify it as such1. This process varies depending on the social, economic, and political forces shaping its formation. Therefore, racialization is a historically specific process (Almaguer, 1994). This section discusses how Chinese enterprises racialize local Tanzanian black workers in relations to salary pay, persona and social interactions.

Racialization is multifaceted and can affect different racial groups

in varying ways, depending on a group's ascribed status position. Some groups, such

as those with White/European appearance and ancestry, are members of a dominant

racialized group and are afforded benefits from their collective racialization. In con-

trast, people of color are members of subordinate racialized groups.

Racialization is multifaceted and can affect different racial groups in varying ways, depending on a group's ascribed status position. Some groups, such as those with White/European appearance and ancestry, are members of a dominant racialized group and are afforded benefits from their collective racialization. In contrast, people of color are members of subordinate racialized groups Edna Bonacich et al (2008).

Edna Bonacich et al (2008) wrote,

"Today's global capitalist system is maintained and structured within a global system of White supremacy. Groups of workers are located within a hierarchically organized, racialized labor system that differentially exploits workers based upon their racialized and gendered location. Dominant racialized labor groups (mainly White/European workers) are in general afforded more privileges than subordinate racialized labor groups (workers of color), who face the denial of basic citizenship rights and higher degrees of exploitation and inferior working conditions".

Therefore the main purpose of racialization of labor is exploitation so as to ensure maximum profit in a capitalist firm. Sautman \& Yan Hairong noted that, racialization of labor aims at exploiting workers at higher rates under worse conditions, usually for worse pay. They added, most seafarers are 'men of color from the Global South who experience unfair treatment due to their race or nationality, including low wages, physical abuse, and a bar on contacting unions. Most of scholars have been writing on labor racialization between white and people of color Edna et al (2008), this section aims at contributing on how factory workers are being racialized by Chinese enterprises in industrial parks in Tanzania, and how Chinese see African workers and how African workers perceive Chinese workers.

Racialization at Chinese enterprises in Africa is different from racialization of Africa from west racialization of global south. Racialization at Chinese firms in Africa is co-constituted by Chinese employers and workers in Africa; Chinese in China, Africans at Chinese companies, African politicians, media, and intellectuals, and their western counterparts. Their perspectives actions form 'overlapping racialization [in which] there are

1 Omi, Michael \& Howard Winant (1986). Racial formation in the United States: from the 1960s to the 1980s. Routledge \& Kegan Paul. ISBN 978-0-7102-0970-2. 
multiple levels of complexity in interracial relations, which may involve both confrontation and collaboration Barry Sautman \& Yan Hairong (2016) argues Chinese racialization at firms in Africa lacks most characteristics set out for North-South invested enterprises. To prove the point on regard that Chinese racialization in Africa is different from west, they added Chinese workers in Africa do not consider Africans workers gets low wages, lower labor standards, or shun struggle. Chinese in Africa view labor standards in some African states as higher than in China.

Tang xiaoyang (2016) on regarding to racialized low wages to Africans wrote, the International Trade Union Confederation's Hong Kong Liaison Office (IHLO) suggested that Chinese companies' wage is among the lowest in many African countries and they usually pay less than other foreign investors. Another criticism is that working conditions in Chinese enterprises are problematic, often involving health and safety hazards and long working hours. To verify this statement, Mr. Ibrahim who was a contractor during establishment of one neighbor factory building said.

"Sometimes when you find yourself in a dangerous position, they tell you to go ahead with the work and just consider production, not safety. If someone dies, he can be replaced tomorrow. And if you report the problem, you'll lose your job."

An intern of racialization of labor, four categories exists that is salary provision, social interactions, work culture and culture stereotype. Analysis on racialization is therefore based on these four grounds.

\subsection{Salary provision}

As illustrated above that, racialization of labor is based on the principle of exploiting labor basing on color on thoer skin. However this section went further and explains racialization of labor is not only based on skin color but also gender.

In my field study work at one Chinese factory (Tang Co), one Chinese enterprises, and a wholesale Chinese enterprises in Kariakoo Dar es salaam Tanzania, I observed a racialized salary pay of 6000 to 8000 Tsh a day (1 dollar is equivalent to 2200Tsh). At the time I was at Tang Co, the most paid African worker was a graduate degree engineer whom at the beginning was paid the same like unskilled migrant labor. Later due to his skillful expertise his salary increased up to $350,000 /=$ a month. Few months later, a Chinese worker from china joined the factory. He was a newly graduated with major in English language. Usually Chinese workers' salaries are kept secret to Africans workers. I managed to find out that he was paid 1624818.25/=TSH. According to ChinaAfrica magazine, data from Ministry of Labor, Social Security \& Service of Kenya shows, and most common types of labor dispute cases are salary below the minimum wage standards and unfair termination 1 . In 2010 in a case that shocked many Zambians and Africans, Chinese executives opened fire on workers who were protesting against poor pay and conditions at the Collum coal mine in the southern Sinazongwe province2. This debate disputes on Chinese paying low salary to local workers is however opposed by many scholars who argue that these low skilled labor don't have any expertise hence the low payment. Xiaoyang TANG (2016) argues on why Chinese companies tend to pay low wages in Africa that;

"To save costs, some Chinese companies reduce their expenditure on employees' welfare such as food, transportation, and healthcare. However, this cannot be simply criticized as exploitation or cruel treatment of African workers, since most of Chinese expatriates, including senior executives, live and work under similar conditions. Unlike Western expatriates who usually stay in exclusive villas and apartments, Chinese often sleep in barrack style dormitories. They work with local workers side by side."

In terms of overtime pay, my field work discovered that, the overtime payments were not in accordance with law stipulated below. Labor law states that "In the event your employees work overtime you will be required to pay them one and one half times the employee's wage for any overtime worked. In the event the overtime hours are worked on a resting day on a public holiday then the employee will be compensated at the rate of double the ordinary rate for every hour worked". At mine time working at SINOMA Company and Tang co. i personally went to work on Sunday, and my salary at time were calculated like normal working hours rather double as law states. However Tanzania's employment and labor relations act of 20043 law defines night as the hours after $8 \mathrm{pm}$ and before $6 \mathrm{am}$. If the employee works at night they shall be compensated at least $5 \%$ of that employee's basic wage for each hour worked at night; if the hours worked are overtime hours, the $5 \%$ shall be calculated on the employee's overtime rate. However, not all employees who work at night are entitled to the 5\% - it is only those who work in the event of emergencies that occur at night. People like watchmen, nurses working on shift, and waitresses working on shift are not entitled to the $5 \%$.

A lot of Chinese enterprises in Africa use high pay promise in the future to provide low pay to Africans.

1 The china africa project. https://chinaafricaproject.com/chinese-companies-labor-dilemma-kenya/. Accessed Sept $14 / 2019$

2 African liberty magazine. https:/www.africanliberty.org/2018/09/27/plight-of-african-workers-under-chinese-employers/ Accessed Sept $14 / 2019$

3 https:/www.ilo.org/dyn/natlex/docs/ELECTRONIC/68319/104204/F-894240970/TZA68319.pdf. Accessed Sept 16/ 2019 
Xiaoyang TANG (2016) regarding low salary to Ethiopians wrote "Huajian's CEO Helen Hai told her Ethiopian employees to be patient and to have foresight when they demanded a raise. She reminded them that Chinese were also poor thirty years ago and it took time and hard work to finally become successful". This is evidenced by a workers at Tang co. who was promised a raise after probation time which was three month according to contract but that raise never came.

Apart from universal low pay among workers at Mkuranga industrial park, there is unequal payment among factory workers. In most of factories in this industrial area division of labor is however based on gender and education level. The study discovered that there is division of labor in this industrial area, male workers tends to do more of manual heavy lifting works and machine operations while female do light manual labor such as packing and packaging. On top of that female labors tend to be more of a part time compared to men. Winfred Osimbo Lichuma (2002) argued, gender inequalities are experienced in industrial labor in Kenya and women are mostly discriminated and marginalized. Most women interviewed during the field study were engaged as casual laborers. In Kenya according to Winfred Osimbo Lichuma (2002) women in industrial labor were found to be fewer as compared to men. However the research result found different findings on labor racial between men and women at Mkuranga industrial park in Tanzania. $60 \%$ of workers working at least at this particular factory are female, who of course their labor is usually temporary and easy to get replaced.

In all the factories I visited in this industrial town, male works at machinery spot and their payments in little higher than women. The citizen newspaper cited international labor organization (ILO) that Tanzania scored 53.6 Gini estimates of the wage inequality, higher than the global average of 35.5. Women are even more affected in this inequality as they are being paid $20 \%$ of what male employees are paid 1 . Example in a day, in Tang Co which in this industrial park its considered the well-paying factory, men earned about 8000 Tsh while women earned 5000Tsh, and top due to the nature of work, as men are machines operators and female are packers most of the time men usually goes home after they finish production while female continue packing until all the products are packed. However men who work as at packaging section usually remains until the entire produced product are packed. In my observation there is no overtime payment system or ration, and most of time it is the employer decided how much to pay after shift if over. At the time of my field at Tang Co. there are few days when I stayed till midnight and at was paid 15,000 Tanzania shilling after the shift, comparing to my fellow workers they were paid 3000 Tanzania shillings.

In neighboring factories however; like in Chinese marble floor factory men were being paid about 5000 to 6000 Tanzania shillings per day while women 3000 to 4000 Tanzania shillings per day. In an Indian factory company men earned $5000 \mathrm{TSH}$ while women earned 4000Tsh. It is because of this low salary in these neighboring factories lead to long queue of temporary workers in Tang Co. factory every morning. The owner of Tang Co is paying high salaries than other factories according to him he said "I want my workers to be contented so that they cannot steal from me". He thinks not radicalizing local worker's salary can bring honest in them.

\subsection{Culture stereotype}

In this subsection, the study intends to look at personal and social views of Chinese workers to Tanzania workers and vice versa. The focus of the study in this section is glance on people to people views between the two groups of different nationality. Some studies conducted about Africans, Tanzanians views in particular towards Chinese shows that there is stereotyping of Chinese by Tanzanians that Chinese investors and workers are rude and persistent, yet not many people could not give specific examples of their interaction that made them think of this personality threat Maho Fujita (2017). In Kenya, Chinese who were constructing Mombasa Kenya railways were views by locals as they don't take into account the cultural differences. They are our guests but orientate strongly towards their own ideology, igniting matters,"2 There are also Chinese personal views on African workers that are lazy and unskilled. Although studies shows that this is merely a stereotyping too as it shows that those Chinese who worked in Africa their stereotyped views were eroded after sometime M Petersen and S Ali. (2018).

Many individuals commented on the personality of Chinese people in Tanzania. More than $80 \%$ stereotyped Chinese workers as rude but few provided specifics. IDD (pseudonym) a factory worker at Tang Company not knowing the keen behavior of Chinese people said;

"My (Chinese) boss usual yells at us even if we are late for 2 minutes, and they don't listen to any excuses".

What most of local laborer respondents mentioned about 'not being respected' is Chinese shouting at them in the workplace and unfair treatment in Chinese companies. In black participants' eyes, Chinese shouting and unfair treatment is taken as an offence. Ganfu Yang (2009) cited Brew and Cairns (2004) that, people from an (low power distance) LPD culture have low consciousness of hierarchy and believe that emotion and work

1The citizen of November 30 2018. https://www.thecitizen.co.tz/news/Tanzania--ranked-third-on-list-of-highest-wage-inequality/18403404875298-752ie9/index.html. Accessed Sept 14/ 2019

2 https://www.dw.com/en/the-racist-face-of-the-chinese-presence-in-africa/a-46223068. Accessed August 18. 2019 
should be separated. To these local employees, shouting is not part of the work, but an emotional outburst from Chinese workers. According to them, such emotional outbursts should not occur in the workplace and emotions and work should be separated. To black employees, shouting was not a manifestation of legitimate power and thus they did not accept 'being shouted at by Chinese supervisors', who intermeshed emotion and power and regarded shouting as part of supervision power.

A Chinese engineer Mr. Wang (pseudonym) who was working at Tang Company seems to think local workers as individuals who never lacks excuses and they never admit even if it is their fault and cant independently work unless close supervisions, pushed and yelled at. Wang takes these local employees as a family therefore he shouts at them when they don't act right. Reaserch done in south Africa by Ganfu Yang (2009) stated that 'To black respondents, 'Chinese shouting at workers in the workplace' is 'offensive' and 'impolite behavior'. But what culture does this shouting expose? In Chinese mindsets, person and issue are intermeshed, implying that employees are part of the group, like a family member. It is normal for parents to shout at their children in Chinese cultural environments".

It is clear that the Chinese culture tendency of adjoin person and issue usually creates problem and misunderstanding for local workers who preferred to 'separate person and issue'. It appeared that in Chinese supervisors' eyes 'Chinese shouting at local workers in the workplace' won them face, respect and showcased their power. However, it planted the seed of a grudge among the black employees who complained about the Chinese not respecting them ${ }^{[1]}$. It must be noted that black employees' lack of deference to their Chinese bosses also offended the Chinese and constituted a challenge to Chinese prestige. Such problematic encounters simmered in their interactions, creating troubling situations for Chinese companies.

\subsection{Chinese- African social interactions}

In this section, the paper explores Chinese workers interaction with local Tanzania workers. The analysis explores Chinese works and living, interactions and mingling with local surrounding society. The kind of Chinese this article refers here are those contract workers who immigrated to Africa for work or trade, not Africa Chinese who were born and raised in Africa and understands African values, customs and culture.

On Chinese socialization with locals, Barry Sautman \& Yan Hairong found that, Chinese in Africa live eat and socialize with local people way more compared to white or other people of color. They wrote "Most Chinese have far less cultural overlap with Africans than do Western expats, yet do not generally display the aloofness that scholars of racialization of labor note at developed country enterprises in the Global South". In other study Hairong Yan, Sautman Barry and Yao Lu argued that, most Chinese in Africa are not self-isolated and not more isolated in Africa than are other Asian migrants and whites there Hairong Yan, Sautman Barry \& Yao Lu (2018). There are contradicting perceptions against Barry and Yan discovery as it is believed to be one sided. Kenyan journalists reported that Chinese workers did not want to share a table at lunchtime with their African colleagues, and that insults and humiliations were the order of the day1. Last year a Chinese worker in Kenya were caught in camera insulting Kenyan and Kenyans president by calling there that they are dirty and are monkeys2. As it is not enough a Chinese restaurant while operating without proper license issued a "no blacks policy" to eat and sleep at that Chinese restaurant and hotel3.

However in my experience across Tanzania I noticed Chinese in Chinese enterprises don't mingle and live together with locals with the exception on those who builds infrastructures like railways and highway...even them they have separate compounds and cafeterias with local blacks. In Mkuranga industrial area local workers live separate mostly in rented ghetto while the Chinese workers and bosses has apartments. Local workers are usually have to walk two to five $\mathrm{km}$ to their residence sometimes at midnight with their day pay on them risking being robbed all the time. Maho fujita's study in Tanga's Chinese enterprises wrote in abroad Chinese workers isolate themselves from the local community and tend to live together as a big family. People in Sinoma live together five minutes away from the construction site in a building they built up. They own a bus, which they collectively use to commute to the construction site from the residential place. In the residential place area has residence building, dining place and entertainment place. There are local servants who take care of housekeeping and patrolling. They also brought Chinese chefs from China, so that they are able to have Chinese food with local groceries all the time. In the dining place they have a cafeteria style big space as well as Chinese style dining table. During relaxing time, they play pool and watch TV. Sometimes they go to the local bars and have drinks with local people. Maho added these Chinese workers', their interaction with local people is limited since only a manager owns a car and there is limited transportation means.

At SINOMA Dar es salaam, local black workers and Chinese workers shared same office but different cafeteria. Upon establishing this SINOMA Dar es salaam group had temporary building where Chinese day workers used to stay in, now that building is being used as Tanzania workers dining rooms and sleeping rooms

$1 \mathrm{https}: / / w w w . d w . c o m / e n / t h e-r a c i s t-f a c e-o f-t h e-c h i n e s e-p r e s e n c e-i n-a f r i c a / a-46223068$. Accessed August 18. 2019

2 https://edition.cnn.com/2018/09/06/africa/kenya-deports-chinese-racist-remarks/index.html. Accessed August 18. 2019

3 https://www.thejournal.ie/kenya-black-people-china-2011639-Mar2015/. Accessed August 18. 2019 
for company's drivers. These former temporary Chinese rooms are made of galvanized sheets, therefore tends to be terribly hot on day time and very cold a night and on Tanzania's dry season. Since most of Chinese workers likes to go downtown city in bars, casino and stay late, drives after driving them back has to stay at this low quality temporary dormitory, or else they have to pay for their transport home on their own. Comparing to other black company where some bosses sometimes either give a drive a taxi fare or let the drivers use the car to home for a night. In my work I managed encountering and talk with three drivers working at a Sahel Inco based in Dar es salaam owned by Somali in collaboration with a British person, the said said "when our bosses return from casino they gave us one car to go home with the condition of returning it next morning safely" said Mr Machima who drives the big Tanzania boss with Somali origin.

As Chinese investment in Africa been gaining pace since the turn of the century, Chinese people/ workers have been immigrated onto the continent with their investments. Chinese and Africans at Mkuranga industrial park interacts each other on daily base not only during work time but also some live together and marry locals. However a study done in Tanga region in Tanzania shows, Chinese workers isolate themselves from the local community and tend to live together as a big family. People in Sinoma (Dar es salaam branch) live together five minutes away from the construction site in a building they built up. They own a bus, which they collectively use to commute to the construction site from the residential place. In the residential place area has residence building, dining place and entertainment place. There are local servants who take care of housekeeping and patrolling. They also brought Chinese chefs from China, so that they are able to have Chinese food with local groceries all the time. In the dining place they have a cafeteria style big space as well as Chinese style dining table. During relaxing time, they play pool and watch TV. Sometimes they go to the local bars and have drinks with local people. Maho added these Chinese workers', their interaction with local people is limited since only a manager owns a car and there is limited transportation means Maho Fujita (2017). This argument contrast that of Barry Sautman \& Yan Hairong (2016) who argued that, Most Chinese have far less cultural overlap with Africans than do Western expats, but they mingle, intaract and live together with Africans in same street and apartments. Barry Sautman \& Yan Hairong added Those Chinese who go further than Western expats in interacting with Africans may have more modest economic positions or a different sense of 'race', one owing to China's socialist legacy or to a sense that China is a developing country.

Chinese habitual practice and the usual way of acting in given circumstances in Africa is different from that of Africans, the may reason for the difference is obviously culture difference and that very few Chinese go to Africa for work with their families. The Chinese go to Africa ready to work 6.5 days/week; Africans want to dedicate time to other pursuits (e.g., family life, religious practices), Chinese focus on profit-making at the expense of overall development; Africans have a broad perspective; they are interested in the socioeconomic development of their community. This paper found that, Chinese workers come to Tanzania without their family, which certainly is a challenging life. It allows Chinese workers to work longer hours without spending time with their family. Also their housework, such as cleaning and cooking, is taken care by Tanzanian locals who are working at Chinese resident place. Due to the above mentioned circumstances Chinese has little or no time at all to mingle with surrounding societies. At Mkuranga industrial park factories are usually open for six days, on Sunday workers goes to church to pray which limits out of work interaction between Chinese workers and surrounding society.

Therefore due to cultural, customs and life ways difference Chinese it is difficult for Chinese and Africans workers interact together apart from work interactions. Drawing example from Tang co. where I worked there for more than sic month, the boss of the company is more understanding towards local society's customs and interacted with his workers in several ways. Since he is Christian, every Sunday together with his Christian workers he usually goes to nearby local church for pray, after pray he often takes some of his workers to go to the beach for swim. Another forms of interactions when one of his worker lost her baby he attended the funeral for three days according to the local society's funeral customs. One of his workers John (pseudonym) said

"Every Sunday the big boss and some Chinese workers we attends morning services in the nearby church, then every afternoon we usually go to beach for swim. He is really a great boss who interacts with us in a most possible way".

Local workers in other factories around Mkuranga industrial park doesn't get the chance to go to church on Sunday mainly because their bosses are not Christian, second due to the fact that they went to work in Africa without their families therefore they tends to work even on Sunday which to majority local workers is for pray and family time.

\subsection{Work Culture}

Chinese' and Tanzanians' culture and work ethics are different; therefore conflict of misunderstanding is due to prevail. Many Chinese business owners have been describing Africans/blacks as lazy, prone to strike for money and individualist oriented Ting-Toomey and Oetzel (2003). Ganfu Yang (2009) did a field study in South Africa noted that, to Chinese, striking would cause conflict and thus striking is the last resort. However, the majority of 
black respondents supported striking, elaborating on its justice: 'strike for money', 'striking is their right'. To them, striking was a quick method to get justice

Chinese employers may speak of African laziness, but define it in terms of comparative work intensity, apply it also to Europeans, other non-Africans, and Chinese of certain regions, and see it as mutable Sautman, Barry, and Hairong Yan. 2014. Maho fujita wrote "A project manager of Sinoma who is a friend of Samera has been working in Tanzania for more than two years. He also has several experiences in other countries in Africa and Middle East. He described Tanzanian workers as lazy and mentioned it is hard to find skilled labor in Tanzania." Field study at Mkuranga industrial park discovered that, there is some elements of laziness to unsupervised unskilled labor, which usually when the boss is not around tends not to do the work as instructed. However, although there some individual who are tends to argue about working condition, long working condition, overtime underpay and adhering with their basic rights then ended up branded as lazy.

One on one discussion was done with the owner of Tang Co who said that;

"Local laborers tends to complain a lot about salary, working time and don't like working overtime at all".

According to Tang Co owner, the reasons why he things local workers are unproductive and inefficient includes lack of training/skill, laziness, a poor time concept, not worrying about losing jobs and not being hardworking. However local workers responded that low pay, long working hours and precarious working conditions made acts the way they act by demanding more pay, overtime work in accordance with Tanzania labor law. Most of factory at Mkuranga industrial park tends to either fire or deduct salary to workers who has disappearing tendencies soon after receiving salary. (Anedo 2012) was quoted Ganfu Yang (2009) that, "Black South Africans' 'disappearing' from the workplace after payday and their lack of urgency demonstrate that black African people want to maximize present rewards and are less prone to saving". The field study witnessed several sick leave, family urgency excuses and time to time disappearing after payday to Tang Company workers which made the factory owner angry and fire most of workers. The study had a honest talk with three workers who were fired for not going to work soon after pay day and I paraphrase, they said that they work seven days a week from 7:50 am to $11 \mathrm{pm}$, sometimes they needs a break.

There is a described working hours according to Tanzania labor law; According to the law, normal working hours per day are 8 hours and these should not be more than 48 hours per week. By including the lunch and prayer time in hours of work, working hours should not be greater than 9 hours a day. At Tang Co and neighboring factories, investors don't pay lunch time and workers are allowed to go and pray but their salaries always get deducted according to time used in praying. Most of coastal workers are of Muslim faith which requires them to play five time a day, and inner land workers most of them are of Christian faith, most of them only prays on Sundays which a work free day. My Chinese boss asked me why these locals would go to pray while they don't have money in their pockets. For him he thinks they are just lazy. My observation concurs with Mato Fujitos that, the challenge of work ethic comes from a cultural/value difference between China and Tanzania as well as their responsibility of work.

Most of Chinese believes Confucianism ethics, according to the Confucians practice, leadership emphasizes a holistic concern for the welfare of employees, a concern for harmony in groups, teamwork, and self-sacrifice. At the same time, Confucian leaders are frugal and demand loyalty and dedication to the organization. They expect employees to work tirelessly for the good of the group, the organization, and the nation. They tend to be autocratic and maintain tight control over the organization. China, more so than most countries clings to its past, and current managerial values, beliefs, and practices are strongly influenced by its Confucian tradition Rarick, Charles A (2008). This practice is way opposite with that of Tanzania.

It is just a stereotype that Africans are lazy. Most of workers in in this industrial town are hardworking individuals who sometime get off work at 2 a.m. in the morning. Some Chinese bosses admitted African workers being hardworking and easy to manage. Chinese factory bosses in Ethiopia especially appreciate the 'hardworking and quick at learning' women workers Shen (2013).

In terms of personality, studies shows that most of Tanzanians thinks Chinese are rude and persistent Maho Fujita (2017). My observation in four Chinese owned enterprises in Tanzania noticed that, there is misunderstanding on what is rude and persistence. Almost all workers told me Chinese usually yells at them and speaks with them at very high tones, they (local workers) sometimes think their Chinese bosses uses insults them in Chinese language. I working with Chinese more than a year in more than two companies however noticed that's not entirely true. There are sometimes yelling at work place but not only to local workers, even Chinese themselves to among each other. I talked with five Tanzanians (studies in china and speaks good mandarin) who happens to be worked and two of them still works in Chinese companies and they said that, most of we Tanzania when Chinese speaks with us we think they are being rude and yelling at us, but that's just Chinese way of speaking. Chinese workers in Tanzania usually most of them don't speak Swahili, and their English are terrible therefore they use Chinese to communicate with people who don't speak Chinese. Most Chinese in Tanzania don't really understand Tanzania's culture and ways of communication hence the confusion. 


\section{Workers livelihood improvement}

In analyzing livelihood changes among factory workers in this industrial park it is important to categorize types of laborers working at this factory. The first category is temporary migrant labor who works at different factories in this park and they get paid the most minimum pay of 3000 to 8000 Tanzania shillings a day. Not having stable job and low pay these workers tends to move factory to factory everyday hence forced to live up every day in factory gate for job applications. Second category is permanent skilled laborers whom are just secondary and high school graduate. This type of laborers came to the factory as temporary migrant labor, but due to their honest, hardworking and tolerance the factory recruited them and become skilled labor. Although they don't have high education but their salary is higher comparing to the first category. They 500,000 Tanzania shillings per month and they are permanent workers. This kind of workers due stable pay at this factory managed to change their livelihood. Third category is university graduate without practical rather theatrical skill to work in the factory. At time of research there were three university graduate engineers who worked at this factory. This type of laborers is being paid above 500,000 Tanzania Shillings a month. Due to bachelor degree, they complained of low pay and unfriendly working and living conditions. They take working at this factory as an opportunity to learn practical skills hence step stone for better job in big company.

Even though local laborers in this industrial park are being racialized in terms of social interaction, pay and different perception of personality and work ethics, but working in this industrial parks factory has improved their livelihoods. Industrial parks are widely known as the means to transform the economy, reduce poverty, provide jobs, and achieve the ambitious aim of transitioning the economy to lower-middle-income. According to Tanzania bureau of statistics this industrial park up to 2018 hired more than 5000 laborers majority of them are migrants.

Apart from temporary workers who come and go and some works for few days, Tang Co. factory at the period of 6 month had 25 local permanent workers. Tang Co. recruited them and became skilled laborers. These 25 workers their livelihoods changed a lot after starting working at this factory. Some of them bought a plot of land; some started to build their own house while some who had family in their origin village sent money to their parents to support their families from subsistence peasant agriculture economy.

The study observed these 25 workers; whom most of them were able to rent a house near the park and brought their family to live with. One of factory worker whom I get a chance to visit his plot site expressed how working at the factory changed his livelihoods. He said he is now able to finish to build his house because he spend little money for daily expenses due to the fact that industrial park surrounding society has cheaper expenditure. He said "although salary is not that high, but life here is cheaper than downtown therefore I am able to save to finish my two bedroom house".

The two university graduate local workers never planned to work at this factory for too long as their dreams are to work as engineers in big Coca Cola Company which is Arusha. At the time of writing this paper, one of university graduate factory worker is now working at Coca Cola Company in Arusha where he get more than one million Tanzania shillings.

\section{Conclusion and discussions}

Africa is vast, comprised of 54 independent nations, of about 1.3 billion people as of October 272020 , and over 3,000 ethnic groups. In addition to French, English, Portuguese, German, Spanish, and Italian, more than 1,000 indigenous languages are spoken. According to the United Nations Statistics Division, the continent can be divided in five geographical sub-regions, namely 1) Northern, 2) Western, 3) Central, 4) Eastern and 5) Southern Africa. However, the major distinction should be drawn between countries north of the Sahara and the ones that form the so-called sub-Saharan Africa. While the history of Africa north of the Sahara (predominantly Arab countries) has been closely linked with that of the Mediterranean basin, the south developed its specific traditions that stayed isolated from major outside influences until the age of European geographical explorations in the 15th and the 16th century when these countries traditional cultures were altered. African ways of life has been changed from its authentic origin like collectivism Ubuntu and Ujamaa to western individualism

Contrariwise to China this is a single country with 56 nationalities but with the Han nationality as the majority who goes to Africa for investment and work has relatively similar cultural values. Bih - Shiaw Jaw and others wrote, there is a substantive relationship between Chinese cultural values (Confucian dynamism, individualism, masculinity, and power distance) and work values (self - enhancement, contribution to society, rewards and stability, openness to change, and power and status) in an integrated model. In their research they found an Interesting link concerning Chinese employees' cross - cultural work values and hard work. Their confirms that, instead of high masculinity and individualism, Confucian dynamism is the main cultural value to foster self - enhancement and most work value of Chinese employees Bih - Shiaw Jaw (2007). In this premises, Chinese work culture asserts hard working, responsibility, working for self-betterment and establish wellbeing is the key factor for success and development.

Due to cultural diversity between china and Africa, the two parties are bound to have misunderstanding, 
disagreements and different opinions on labor relations, equality, racialization, and social interactions. Cultures are dynamic therefore as time passes culture is bound to change with or without external force. Chinese who goes to invest in Africa should know Africa's culture dynamics and diversities so as to avoid unnecessary misunderstandings

Racialization, different opinions and cultural difference between china and Africa should be understood so as to avoid misunderstanding. In general most African are more individualist oriented, whereas Chinese were strongly collectivist, probably explains why the two groups had problematic encounters in the building industry, labor racialization and interaction at workplace. Being strongly collectivist, Chinese employers considered company interests more important than employees' individual rights and intermeshed person and issue, meaning that work, relationship and emotion were mixed up while most of local employees do not compromise their individual rights for the benefit of company interests. Local laborers strong sense of rights in respect of complaining about low salaries and poor working conditions in Chinese companies often ended up with the Labor Department and/or led to strikes, which left the Chinese employers disappointed and angry, thus creating a problematic encounter.

Some scholars have been arguing to the fact that, labor law should be the guideline to settle any sort of labor racialization and disputes that there is a lot to do to avoid malpractices like long working hours, underpay, poor working condition, long overtime working hours, female visa vise male worker pay disparity and working without contract1'2'3'4'5 of Chinese workers towards African workers and African workers to Chinese workers as well Isabel MORAIS (2009). The presence of Chinese companies in Africa is testing the labor laws of various African countries. There have been concerns over Chinese labor practices, often viewed as unfair, with various cases reported of poor and harsh working conditions. Former Zambian leader Michael Sata was well known for speaking out against Chinese labor practices. Sata denounced China's role in Africa and as part of his campaign promised to stop Zambia from becoming a "dumping ground for their human beings" 6 .Labor laws and policy in Tanzania prohibit such malpractices but Tanzania being a developing country is unable to implement these policies. Tanzania labor law states that "The maximum ordinary working hours that an employee is allowed under the law to work is forty five (45) hours meaning nine (9) hours a day. The nine hours are exclusive of the one hour daily lunch break. The lunch break is to be provided after five hours continuous working time. Lunch break is unpaid time and is the employee's own time because they are not paid for lunch breaks. Any hour (s) in excess of the forty five hours must be compensated as overtime hours. It is also prohibited for an employee to work more than twelve hours in a day". In terms of overtime work, the law puts a limitation on the number of overtime hours that an employee can work. Section 19 (3) (b) prohibits an employee to work more than 50 overtime hours in any four week cycle. The law also prohibits worker to require or permit an employee to work overtime except in accordance with an agreement. However, even under an agreement employer and employee cannot negotiate for more than the average number of overtime hours provided for under the labor laws that is 50 hours.

During field research, local workers were asked if abiding by labor law is the best way to solve labor problems in Chinese companies. 60 percent of black respondents disagreed that labor law was the best way to solve labor problems in Chinese companies, while 87.5 percent of Chinese respondents agreed with the statement although said there should be more into it than abiding to labor laws.

Nonetheless, it is for the best interest of everyone to understand Africa's diversity culture, customs and laws before investing or doing business in Africa. A lot can be avoided if there is mutual respect, mutual understanding and economic cooperation between Tanzania and investors. Even though there is little labor racialization between Chinese and Africans but basically it is perpetuated by misunderstanding between the two parts. Cultural, political, economic and social dimensions should be observed and learned to avoid future misunderstandings. However it should be understood that, African culture went through few alteration during western imperial occupation in Africa, Chinese in Africa should know better not to repeat the same by imposing Chinese ways which does not fit Africa's context rather learn understand and have a mutual coexistence.

Conclusively, even though Chinese Company racializes Africa's black laborers, but relatively, compare to Indian enterprises that has deeper and embedded contact in Africa are well off in term of racialization, Chinese Companies racialization of labor in Tanzania is light and mild than Indian Company. Some Chinese; depends on projects they do mingle and live with local Tanzanians some even get married to local Tanzania girls. I witnessed two Chinese at Mkuranga industrial park married local girls and living with them, unlike SINOMA

$1 \mathrm{https} / /$ www.dw.com/en/the-racist-face-of-the-chinese-presence-in-africa/a-46223068. Accessed Sept 16/2019

2 https:/www.theguardian.com/world/2014/jul/17/chinese-ambassador-tanzania-china-africa-relationship-ivory-smuggling-counterfeit. Accessed Sept 16/ 2019

3 https://www.independent.co.uk/news/world/asia/china-fake-food-sector-unlicensed-products-knock-offs-supply-chain-contaminationpublic-health-a7880341.html. Accessed Sept 16/2019

4 https://nationalinterest.org/blog/buzz/why-china-taking-over-africas-resources-one-country-time-70526. Accessed Sept 16/ 2019

$5 \mathrm{Ibd}$.

6 https://www.africanliberty.org/2018/09/27/plight-of-african-workers-under-chinese-employers/. Accessed Sept 16/ 2019 
(Dar es Salaam branch) where they don't mingle or live together with local workers. Even though there is negative labor racialization on salary, interactions and different perception between the two parties but these foreign investors provides a sound employment opportunity to locals hence livelihood improvement to most of Tanzanians and economy at large.

Chinese unlike other racializers (westerners and Indians at the time of contact with Africa) does not see African culture (religion) any lesser, and don't try to change local peoples religions like what the Arabs, westerners did. Chinese racialization is not intuitional in china like in India (caste system) or in Americas, therefore it is absurd to take Chinese racialization in Africa and put them in the same pot with Indians, Arabs or westerners.

\subsection{Discussions}

Since there is more than Chinese factories at Mkuranga industrial park, there is a need to look on other factories' labor racialization at these industrial park. To get the overall glimpse of labor racialization at Mkuranga industrial park from other non-Chinese factories it is better to compare with other foreign enterprises located at different industrial parks. Therefore the paper will look on the Indian owned factory present at this industrial park, not only that but also this subsection will observe how local Indians interact, racialized and live with local black residents.

Racialization of labor in African countries usually originates from countries investors are from. I however believe that, there are severe racism and racialization at place where investors originates. Marie-Aude Fouéré (2017) quoted (Adam 2006) that, they (Indians) in Tanzania represented all the socio-professional statuses of the caste system and adhered to varied local customs. In short, they formed "a sort of small replica of India". Like India's caste system in India where black people are racialized there is passive racism in china like being denied a job or lower salary due to being black or rudely photographed1, but black students in India are sometimes spat on, insulted and when renting apartments are being charge three times higher2.

Comparing between Chinese and Indian factories in the park the study found that, Chinese employers provide slightly higher salary than Indian investors and the level of racialization differ too. To verify this, a former bodyguard t Nelson Mandela Sam Prakash was quoted by the citizen saying Indians are the most racist in the world3.

Monetarily, they (Chinese investors) argue that, Chinese employers pay more than other competitors Maho Fujita (2017). Marie-Aude Fouéré (2017) wrote, "Most Chinese businesses employ African staff as waiters, cooks, tailors, vendors or guards." In residential apartments, domestic workers are also African. All of them complain about low wages, usually insufficient for a living. Figures vary, not only depending on profession and skills, but also on employers themselves. According to the employees interviewed for this study, these figures would range from 10,000 to 20,000 shillings a month for house help staff and between 30,000 and 50,000 shillings for other workers, that is, between 6 and 35 euros per month. The study found that, local bosses of (Indian origin) are said to pay their employees badly" comparing to the field work conducted at Mkuranga industrial park, Tang Co. pays 8000Tzs for a day, while another competitor, Simba cements co. (India Cement Company) pay 3000Tzs for same unskilled male labor. Marie-Aude Fouéré reffered (2013) called Indians as exploiters while Africans as idlers. Fujita discovered that, Chinese investors claim that they (Chinese) give locals enough monetary incentive than other foreign investors (Indians, local black and white) Maho Fujita (2017).

There are fairly amount of Indians who have been in Tanzania for decades. They do understand Tanzania culture and values and they live in the society together with Tanzanians. But they don't intermingle with black Tanzanians; the only mingling is during working hours. Majority of them lives in cities and towns and opens shops and factories. Present-day Tanzanian society is not a melting pot in which people of different backgrounds would blend together peacefully; it rather exemplifies a plural society or double-faced communitarianism in which people live side-by-side but separately - at least when it comes to "Indians" and "Africans" Marie-Aude Fouéré referred (2013). This research found that, workers employed in these (Indians) shops and factories usually complain on Indians mistreatments towards black workers like pay cuts and salary delay.

The nature of work and lower salary at this industrial park creates a condition where by educated labor at these factories sees working there as a stepping stone to better paying job at enterprises. These newly established factories provided learning and training opportunity to unskilled laborers for better pay job opportunity. At the time I was working at Tang Co, at the period of six months, four university graduate joined and left the company according to them due to unsatisfactory salary and mistreatments at the factory. One worked only for three month, some two while others didn't even last a month. They used these factories at this industrial park as their

1 https://medium.com/@jakepagano/african-students-encounter-institutional-racism-at-a-top-chinese-university-raisingurgent-cd8a6eeb1fa4. Accessed Aug 22, 2019.

$2 \mathrm{https} / / /$ fotoroom.co/african-portraits-mahesh-shantaram/ August 22, 2019.

$3 \mathrm{https} / /$ citizen.co.za/news/south-africa/2015127/watch-indians-are-the-most-racist-in-the-world-says-mandelas-formerbodyguard/ accessed August 22, 2019. 
stepping stone to a better job. Supporting the argument Barry Sautman \& Yan Hairong argued, some Chinese also racialize Africans by forcing them (African) to work excessively long hours, with ought overtime pay and have accommodations often dirty, cramped, and heavily monitored. Two workers (university graduate) of Tang Company left the job and went to Tanzanian owned Coca-Cola Company. John a young newly employee at Tang Company at the time of joining he told me that;

"I joined here because I need to get experience, I know this company don't pay me well and I work longer working ours, but after few month am sure I will get a high paying job"

During my field study experience, I moved from one company to another first of all due to low salary, and second I wanted to make a comparative study between different enterprises in Tanzania. My first Chinese company was Tang Co, due to being a fresh master's graduate with Chinese language skills, I was paid 800000TSH. I worked for five month, and then I went ahead and work at Kariakoo. Kariakoo is one of Tanzania's biggest market place with an increasing number of Chinese big and petty business men and women. At Kariakoo, this enterprise was owned by a Chinese business woman who imports mainly mosquito's nets, fancy curtains, among many. At this Chinese enterprise I was being paid much high than previous job, 15000000 TSH. My salary was much high than other workers I found there not because I have high higher education comparing to them, but my boss wanted not only my Chinese language expertise but also its because I did understood Chinese culture, in her own words "I understand her and Chinese culture".

I worked there for three month before I joined a Tanzania -Kenyan's co-owned factory in Arusha. At this factory I was responsible in managing Chinese workers who were engineers at this factory. It is at this factory I saw the difference from Chinese enterprises. Salary became high, I was provided with a house and a transport. We worked six days a week and I stayed at that company for 2 month. May payments at this factory was 70 USD per day and was paid weekly.

My personal working story is similar to many graduate with the similar expertise like was, they only work in Chinese enterprises temporality unless high salaries are offered. Most of Tanzania workers I worked with during my field study time prefer to work at white owned companies or local owned companies which have local and foreign workers too. According to them, at these companies, their labors are not racialized and are being treated equally like other foreign expats. Local owned companies pay its workers according to workers capability and expertise one holds not due to skin color.

On my winter holiday when I was working with SINOMA east Africa, a human resources lady started discussing with me salaries cut issues. At SINOMA, a project manager was being paid 2400000TSH, almost similar to some Chinese workers. She asked me "do you think it is reasonable a Tanzania project manager to be paid that much, similar to Chinese project manager?" considering they both has same experience plus the Tanzanian worker graduated his masters in Germany, I was perplexed did not know what to answer her. The study found that, Chinese racialization of black labor is not as severe as some sees it, there are however few closed minded Chinese workers who still don't value Africa/ Tanzania workers as equal to them even if they have same education to them. Although there are some selected racialization Chinese workers but generally Chinese racialization is culture racialization; on level of skills, educations and working capacity. Chinese racialization to black laborers is not racial rather ones group ability of doing things and working. However to reduce the extent of racialization can be reduced if Africa's governments should tighten their and implement their lax labor laws to avoid these unfair racialization.

\section{References}

Almaguer, T. (1994). Racial fault lines: The historical origins of White supremacy in California. Berkeley: University of California Press.

Almaguer, T. (1994). Racial fault lines: The historical origins of White supremacy in California. Berkeley: University of California Press.

Almaguer, T. (1994). Racial fault lines: The historical origins of White supremacy in California.

Berkeley: University of California Press.

African liberty magazine. https://www.africanliberty.org/2018/09/27/plight-of-african-workers-under-chineseemployers/ Accessed Sept 14/ 2019

Ali A. Mufuruki et al. (2017). Tanzania's industrialization journey, 2016-2056: from agrarian to a modern industrialization state in forty years. Moran (E.A.) Publishers Limited, Nairobi, Kenya

Aljazeera. Jul 27, 2014. https://www.youtube.com/watch?v=_KM06hTeRSY\&t=2188s. Accessed Sept 7.2019

Aljazeera. Jul 27, 2014. https:/www.youtube.com/watch?v=_KM06hTeRSY\&t=2188s. Accessed Sept 7.2019

Almaguer, T. (1994). Racial fault lines: The historical origins of White supremacy in California.

Awil Mohamoud et al (2014). Climate change, development, and migration: an African Diaspora perspective. Germanwatch e.V. Bonn

Awil Mohamoud, Alpha Kaloga \& Sönke Kreft. Assessing the Impact of Climate Change on Migration and Conflict* 
Beegle et al, (2011). "Migration and economic mobility in Tanzania : evidence from a tracking survey ...

Berkeley: University of California Press.

Burke, Christopher and Corkin, Lucy (2006). "China's interest and activity in Africa's construction and infrastructure sectors". November: Centre for Chinese Studies. Page 53. Available on http://www.ccs.org.za/wpcontent/uploads/2009/04/dfid-3rd-edition.pdf

Caroline Zickgraf, (2019).Climate Change and Migration Crisis in Africa Clionadh Raleigh etl Assessing the Impact of Climate Change on Migration and Conflict*

Charles A. Rarick. (2008). Confucius on Management: Understanding Chinese Cultural Values and Managerial Practices. Journal of International Management Studies, Vol. 2, No. 2,

chinaafricaproject magazine https://chinaafricaproject.com/chinese-companies-labor-dilemma-kenya/ accessed Sept 14/ 2019

Chistiane Flohlich and silja Klepp (2018). Climate Change and Migration Crises in Oceania. Toda peace institute

Citizen newspaper. Wednesday April 17 2019. https:/www.thecitizen.co.tz/news/1840340-507609489ew90/index.html accessed Sept 10th. 2019.

Dijk, M. P. v. (Ed.). (2009). The new presence of China in Africa (EADI). Amsterdam: Amsterdam Univ. Press. https:// nbn-resolving.org/urn:nbn:de:0168-ssoar-271450

Durkheim, Emile (1984). The Division of Labour in Society. Trans. W. D. Halls, intro. Macmillan: Free Press, London. UK

E Durkheim. (1984). The Division of Labour in Society. Trans. W. D. Halls, intro. Lewis A. Coser. New York: Free Press , 1997

Edna Bonacich et al (2008). The Racialization of Global Labor University of California, Riverside

Edna et al (2008). The Racialization of Global Labor. https://doi.org/10.1177/0002764208323510

Hairong Yan, Sautman Barry \& Yao Lu. (2018). Chinese and 'self-segregation' in Africa.

Hofmann et al (2007). Contrasting Perceptions: Chinese, African, and European Perspectives on the ChinaAfrica Summit

Howard W. French. (2014). China's second continent; how a million migrants are building new empire in Africa. New York. Alfred A. Knopf, a division of Random House, LLC

HPB Moshi \&JM Mtui (2008). Scoping studies of china- africa economic relation:the case study of Tanzania. Economic research bureau 11

https:/citizen.co.za/news/south-africa/2015127/watch-indians-are-the-most-racist-in-the-world-says-mandelasformer-bodyguard/ accessed August 22, 2019.

https://edition.cnn.com/2018/09/06/africa/kenya-deports-chinese-racist-remarks/index.html. Accessed August 18. 2019

https://fotoroom.co/african-portraits-mahesh-shantaram/. Accessed August 22, 2019.

https://fpif.org/john-bolton-says-he-wants-to-protect-africa-from-predatory-chinese-behavior-what-aboutwashingtons/. Accessed Sept 7.2019

https://medium.com/@jakepagano/african-students-encounter-institutional-racism-at-a-top-chinese-universityraising-urgent-cd8a6eeb1fa4. Accessed. August 22, 2019.

https://nationalinterest.org/blog/buzz/why-china-taking-over-africas-resources-one-country-time-70526. Accessed Sept 16/ 2019

https://nexia.com/insights/global-insight/investing-in-tanzania/. Accessed August 9, 2019

https://www.africanliberty.org/2018/09/27/plight-of-african-workers-under-chinese-employers/. Accessed Sept $16 / 2019$

https://www.dw.com/en/the-racist-face-of-the-chinese-presence-in-africa/a-46223068. Accessed August 18. 2019

https://www.dw.com/en/the-racist-face-of-the-chinese-presence-in-africa/a-46223068. Accessed Sept 16/ 2019

https://www.ilo.org/dyn/natlex/docs/ELECTRONIC/68319/104204/F-894240970/TZA68319.pdf. Accessed Sept $16 / 2019$

https://www.independent.co.uk/news/world/asia/china-fake-food-sector-unlicensed-products-knock-offs-supplychain-contamination-public-health-a7880341.html. Accessed Sept 16/ 2019

https://www.mining.com/south-african-report-highlights-chinese-labor-abuses-in-zimbabwe-and-zambia-80476/. Accessed Sept 7.2019

https://www.theguardian.com/world/2014/jul/17/chinese-ambassador-tanzania-china-africa-relationship-ivorysmuggling-counterfeit. Accessed Sept 16/2019

https://www.thejournal.ie/kenya-black-people-china-2011639-Mar2015/. Accessed August 18. 2019

https://www.trademarkea.com/news/tanzania-economic-zones-key-to-industrialisation-says-meru/. August 9, 2019

https://www2.deloitte.com/content/dam/Deloitte/tz/Documents/tax/Economic\%20Outlook\%202016\%20TZ.pdf. Accessed August $9^{\text {th }}, 2019,3: 43 \mathrm{pm}$ 
Isabel MORAIS. (2009). "China Wahala": the Tribulations of Nigerian "Bushfallers" in a Chinese Territory"Journal of global cultural studies

Jacoby, U. (2007). The new partnership between China and Africa for aid and trade. Finance and Development, June, Vol. 44, No.2.

Joseph Patrick Ganahl. (2013) Corruption, Good Governance, and the African State; A Critical Analysis of the Political-Economic Foundations of Corruption in Sub-Saharan Africa. Potsdam University Press

K. Beegle. (2011). Patterns of Migration in Tanzania

M Petersen and S Ali. (2018) Chinese Migrant Perceptions of Africans: Understanding Confucian Reflexive Politics in Southern Africa

Maho Fujita (2017) Chinese Involvement in Tanzania and Its Local Impacts, Bucknell University, mf045@bucknell.edu

Marie-Aude Fouéré reffered (2013). Indians are exploiters and Africans idlers ! The production of racial categories and socio-economic issues in Tanzania. HAL Id: halshs-01493027 https://halshs.archivesouvertes.fr/halshs-01493027

Michael Burawoy. (1985)The Politics of Production: Factory Regimes Under Capitalism and Socialism

Muhidin J. Shangwe (2017). China's Soft Power in Tanzania: Opportunities and Challenges, Shanghai Institutes for International Studies China Quarterly of International Strategic Studies, Vol. 3, No. 1, 79-100

New York Times. https:/www.nytimes.com/2018/10/15/world/africa/kenya-china-racism.html. Accessed Sept 7.2019

Omi, Michael \& Howard Winant (1986). Racial formation in the United States: from the 1960s to the 1980s. Routledge \& Kegan Paul. ISBN 978-0-7102-0970-2.

Pun Ngai. (2015), Made in China: Women Factory Workers in a Global Workplace

Raphael Kaplinsky and Mike Morris (2009). Chinese FDI in Sub-Saharan Africa: Engaging with Large Dragons.united kingdom. The European Journal of Development Research

Robert Ebihart Msigwa (2013). Determinants of Internal Migration in Tanzania. Journal of Economics and Sustainable Development.

Sautman B (1994). Anti-Black Racism in Post-Mao China Cambridge University press

Sautman, Barry, and Hairong Yan. 2014a. "Chinese, Africans and the Discourse of Laziness." Paper, Chinese in Africa/Africans in China Research Network conference, Guangzhou, December 13.

Shen,Xiaofang.2013.“PrivateChineseInvestmentinAfrica:MythsandRealities."Policy Research Working Paper 6311, World Bank. http://documents.worldbank.org/ curated/en/2013/01/17159618/private-chineseinvestment-africa-myths-realities.

Standard digital. https://www.standardmedia.co.ke/article/2001287179/revealed-sgr-workers-treated-badly-bychinese-masters. Accessed Sept 7.2019

T, Bruno (2013). Why and how do capitalists divide labor? From Marglin and back again through Babbage and Marx. Review of Political Economy, Taylor Francis (Routledge), 2013, 25 (2), pp.254-272. ff10.1080/09538259.2013.775825ff. ffhal-00763837f

TANG XIAOYANG. (2016). Does Chinese Employment Benefit Africans? Investigating Chinese Enterprises and their Operations in Africa. Center for African Studies, University of Florida

The economist. https://www.economist.com/leaders/2019/03/07/the-new-scramble-for-africa. Accessed Sept 7.2019

The guardian. https:/www.theguardian.com/us-news/2018/dec/13/us-john-bolton-africa-policy-russia-china. Accessed Sept 7.2019

The telegraph. https:/www.telegraph.co.uk/global-health/climate-and-people/trump-admin-vows-tackle-russiachinas-predatory-practices-africa/. Accessed Sept 7.2019

Ting-Toomey, S. \& Oetzel, J.G. (2003). Cross-cultural face concerns and conflict styles: Current status and future directions. In W.B. Gudykunst (Ed), Cross-cultural and intercultural communication (pp.127-147). Sage Publications: Thousand Oaks.

Voice of America Kenya. https://www.voanews.com/africa/kenya-tells-workers-learn-chinese-despite-abuseallegations. Accessed Sept 7.2019

W, Elizabeth. (2007). Explaining the Gender Division of Labour: The Role of the Gender Wage Gap 1CMPO, The University of Bristol

W. Rodney, K. Tambila and L. Sago. (1983), Migrant Labor in Tanzania during the Colonial Period. Hamburg: Institut für Afrika-Kunde

Washington post https:/www.washingtonpost.com/politics/bolton-says-predatory-china-is-outpacing-the-us-inafrica/2018/12/13/7b906626-fee2-11e8-83c0-b06139e540e5_story.html. Accessed Sept 7.2019

World Bank. (2013), Turn Down the Heat: Climate Extremes, Regional Impacts, and the Case for Resilience

Xinhuanet, "China donates agricultural machinery to Tanzania, "Forum on China-Africa Cooperation, November 17, 2015, accessed March 14, 2017, http://www.fmprc.gov.cn/zflt/eng/jmhz/t222842.htm. 